\title{
The phenology of wetland submerged macrophytes related to environmental factors
}

\author{
Sara Calero, William Colom and Maria A. Rodrigo \\ Integrative Ecology Group, Cavanilles Institute for Biodiversity and Evolutionary Biology, University of \\ Valencia, Catedrático José Beltrán 2. E-46980-Paterna, Valencia, Spain. \\ *Corresponding author: sara.calero@uv.es
}

Received: 02/01/2015 Accepted: 30/06/2015

\begin{abstract}
The phenology of wetland submerged macrophytes related to environmental factors

Little information is available about the phenology (i.e., the timing of recurrent events in life cycles) of submerged aquatic plants although they play a key role in wetlands. To establish a long-term data series concerning the phenology of aquatic plants, we are monitoring an artificial shallow pond in a depression between sand dunes in Albufera de València Natural Park (Spain). The macrophyte diversity in the pond is moderate: two angiosperms (Potamogeton pectinatus and Utricularia australis) and four charophytes (Nitella hyalina, Chara aspera, Chara vulgaris and Chara hispida). We continuously monitored the underwater temperature, at two sites and depths, through the use of probes with data-loggers. Other water variables (such as sestonic chlorophyll $a$, salinity, $\mathrm{pH}$ and oxygen) were monitored monthly. Samples of macrophytes were collected frequently to record the emergence and maturation of flowers/seeds in angiosperms, and sexual organs/oospores in charophytes. The relationship of phenological features to water temperature was tracked by calculating growing degreedays (GDD). The timing of the emergence and maturation of the sexual organs (antheridia and oogonia) of $C$. hispida was dependent on the water depth: both sexual organs had already ripened by 70 GDD in shallower water (where there was no clear interruption of sexual reproduction), whereas in deeper water antheridia achieved this at 270 GDD, oogonia at 325 GDD. Oospores required twice as much heat to ripen in deeper water as in shallower water. Although N. hyalina had a similar phenology, it required more time and accumulated heat to become fertile: more than 1000 GDD were needed to ripen the sexual organs and oospores. C. vulgaris' sexual reproduction was detected in spring, whereas $C$. aspera specimens remained fertile during the whole year. Both studied angiosperms flowered in late spring and mid-summer. P. pectinatus produced fruits at $900 \mathrm{GDD}$, whereas neither fruits nor seeds were detected for $U$. australis. These initial data represent a first glance at the life cycle of the submerged macrophytes inhabiting this pond as well as at the basic environmental conditions that affect their phenology and which, in turn, are also influenced by climate change. It represents the first detailed study of the phenology of Mediterranean charophytes from wetlands, and it lays the foundation for our forthcoming research.
\end{abstract}

Key words: Angiosperms, aquatic plants, charophytes, Mediterranean ponds, growing degree-days.

\section{RESUMEN}

\section{La fenología de los macrófitos sumergidos de humedales en relación con factores ambientales}

Existe poca información disponible sobre la fenología (el ritmo de los eventos recurrentes de los ciclos vitales) de las plantas acuáticas sumergidas, a pesar de que desempeñan una importante función en los humedales. Con el objetivo de establecer una serie temporal larga sobre la fenología de las plantas acuáticas, estamos monitorizando una laguna somera creada en una depresión interdunar en el Parque Natural Albufera de València, que presenta una diversidad de macrófitos moderada: dos angiospermas (Potamogeton pectinatus y Utricularia australis) y cuatro carófitos (Nitella hyalina, Chara aspera, Chara vulgaris y Chara hispida). Hemos monitorizado de forma continua la temperatura subacuática, en dos zonas de distinta profundidad, mediante el uso de sondas con registradores de datos. Hemos medido mensualmente otras variables acuáticas. Las muestras de los macrófitos se recolectaron frecuentemente y se registró la aparición y maduración de flores/semillas en angiospermas y de órganos sexuales/oósporas en carófitos. Las características fenológicas se relacionaron con la temperatura del agua mediante el cálculo de la "suma térmica-grados día" $(G D)$. C. hispida mostró diferente ritmo en la aparición y maduración de sus órganos sexuales (anteridios y oogonios) en función de la profundidad: ambos maduraron con 70 GD en las aguas 
someras (donde parece que la reproducción no se interrumpió), mientras que en aguas más profundas los anteridios y los oogonios maduraron tras 270 y 325 GD, respectivamente. Las oósporas necesitaron el doble de calor para madurar en las aguas más profundas. Aunque N. hyalina presentó una fenología similar, necesitó más tiempo y calor acumulado para ser fértil: más de 1000 GD para madurar los órganos sexuales y oósporas. La reproducción de C. vulgaris se detectó en primavera, mientras que los ejemplares de C. aspera permanecieron fértiles durante todo el año. Las dos angiospermas estudiadas florecieron a principios de primavera y mediados de verano. P. pectinatus produjo frutos a los 900 GD, mientras que no se detectó ningún fruto o semilla en U. australis. Estos datos iniciales suponen una primera imagen del ciclo de vida de los macrófitos sumergidos de esta laguna, así como de las condiciones ambientales básicas que afectan a su fenología, las cuales están influidas por el cambio climático. Éste representa el primer estudio detallado de la fenología de carófitos mediterráneos de humedales y establece las bases para nuestras próximas investigaciones.

Palabras clave: Angiospermas, plantas acuáticas, carófitos, charcas mediterráneas, suma térmica.

\section{INTRODUCTION}

Submerged macrophytes play a key role in ecological and biochemical processes of aquatic ecosystems in general, and wetlands in particular. They improve water clarity and quality as well as providing food and shelter for different groups of fauna, such as fish, waterfowl or invertebrates (Carpenter \& Lodge, 1986). However, human activities are currently threatening wetlands, and, hence aquatic plants, through factors such as eutrophication, biological invasions, or habitat destruction. The term "global change" refers to all these anthropogenic alterations of the basic processes of the Earth, including the widely known climate change (Vitousek, 1994). It is expected that changes in the hydrological regimes, among others, will affect the quantity and quality of the water supply to wetlands (Erwin, 2009). According to projections in the Mediterranean region, the rising global temperature will be coupled with a decrease in precipitation and a longer summer drought, increasing aridity (Richardson et al., 2013). Thus, Mediterranean wetlands are more vulnerable than others in the current changing environment. Hence, the macrophytes that inhabit them are also more vulnerable.

Variations in different environmental factors, such as temperature or precipitation, highly influence the distribution and abundance of submerged macrophytes (Lacoul \& Freedman, 2006). Their sensitivity to both short and longterm changes makes them highly useful as water quality indicators (Aguiar et al., 2014). Among submerged macrophytes, charophytes (green macroalgae) are especially vulnerable to environmental factors such as the ones affected by climate change (Rey-Boissezon, 2014; Rojo et al., 2015). Historical worldwide records of charophyte distribution have already shown the disappearance of several populations and the decline of rarer species, while predictions note the increase of some species (winners) and the decrease of others (losers) within the current ongoing ecological change scenario (Auderset Joye \& Rey-Boissezon, 2015). Moreover, populations of the same species can even be affected in different ways (Rojo et al., 2015).

An approach that is commonly used to track the effects of climate change on species is the study of their phenology (Parmesan, 2006), i.e., the monitoring of the timing of the recurrent events of their life cycles, such as flowering. Although much is known about the long-term effect of climate change on the phenology of terrestrial ecosystems (Richardson et al., 2013), there is little information regarding aquatic systems and even less regarding aquatic plants. Some studies focus on emergent macrophytes by means of remote sensing observations (Alahuhta et al., 2011), whereas others focus on floating plants (Peeters et al., 2013) and their interaction with submerged macrophytes based on in situ observations of cover (Netten et al., 2011). However, it is difficult to find studies with species-level observations of submerged 
macrophytes (Rey-Boissezon, 2014). This latter approach allows researchers to precisely study different phenophases (stages of the life cycle) of the same or various species, including vegetative and reproductive ones, and to scale phenology from a local to a regional level (Chuine et al., 2000). Species, or phenophases, may differ in their responses to rising temperatures and so disrupt their synchronic and interdependent interactions with other organisms or other particular life-cycle stages (Donnelly et al., 2011).
In this context, to create a long-term data series on the phenology of aquatic plants, we have, since 2013, monitored a Mediterranean shallow pond in a depression between sand dunes. The pond was created in 2007 within Albufera de València Natural Park (Spain) as part of the restoration of the seashore dune front and its associated water bodies (locally called mallades). The pond currently contains medium macrophyte diversity: the charophyte species Chara hispida, Chara aspera, Chara vulgaris and $\mathrm{Ni}$ -

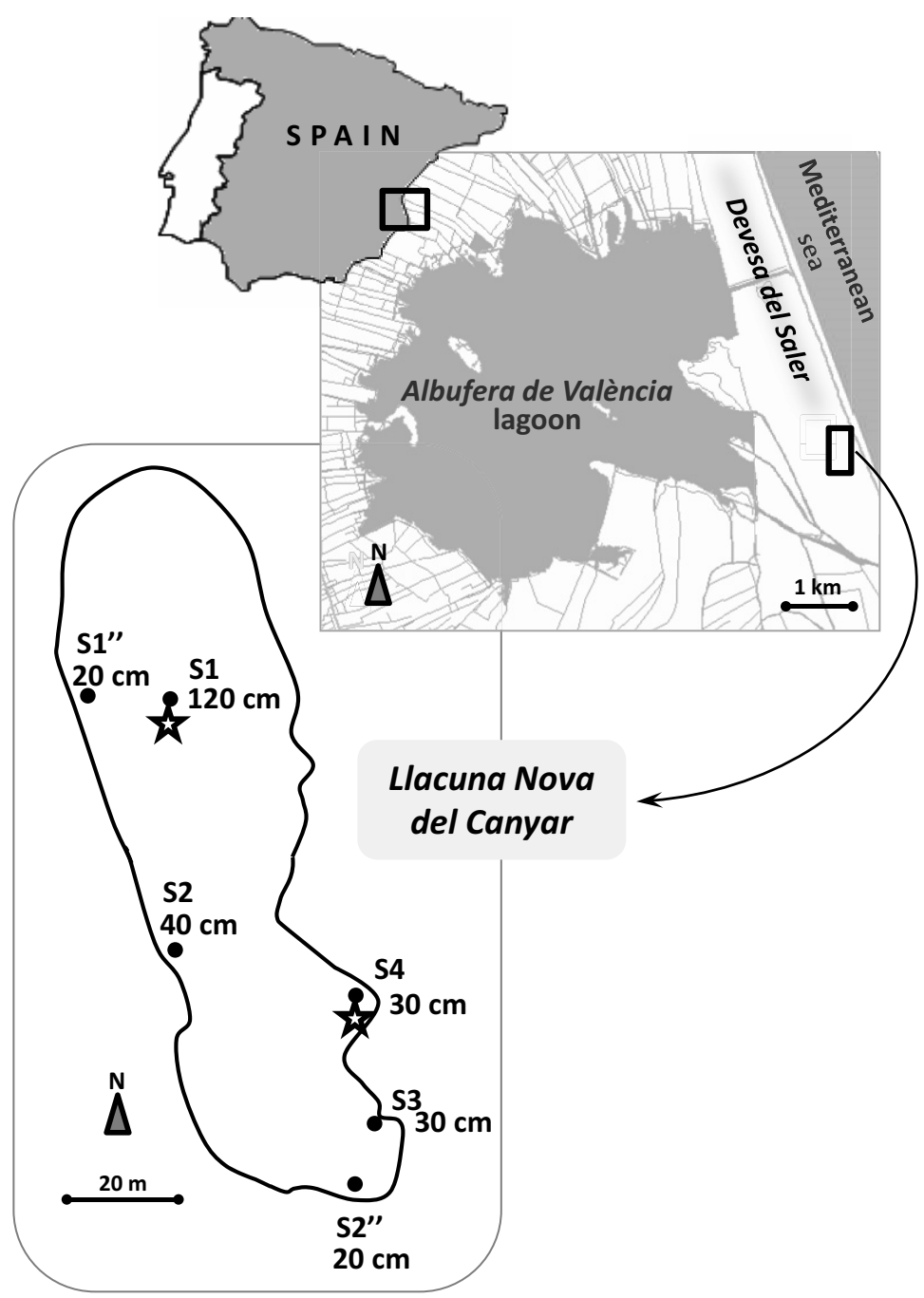

Figure 1. Location of Llacuna Nova del Canyar within the Devesa del Saler sand bar and Albufera de València Natural Park, in Spain. Positions and water depth data for each sampling stations (S1, S1", S2, S2", S3 and S4) are also shown. Stars indicate the position of temperature probes. Localización de la Llacuna Nova del Canyar en la barra arenosa de la Devesa del Saler y el Parque Natural Albufera de València, en España. También se muestran las posiciones y los valores de profundidad del agua para cada estación de muestreo (S1, S1" S2, S2", S3 y S4). Las estrellas indican la posición de los sensores de temperatura. 
tella hyalina, the submerged angiosperm Potamogeton pectinatus, and the free-floating plant Utricularia australis. Here, we present the initial data concerning the reproductive phenology of these species in relationship to certain environmental factors such as those reflected in temperature data. We used the accumulated growing degree-days parameter to estimate the heat required by each species to produce its sexual structures.

\section{METHODS}

\section{Study area}

The Llacuna Nova del Canyar (LNC hereafter, $39^{\circ} 19^{\prime} 41.1^{\prime \prime} \mathrm{N}, 00^{\circ} 18^{\prime} 16.1^{\prime \prime} \mathrm{W}$, Fig. 1) is an interdunal shallow pond created as part of the EU funded project Life Enebro (2004-2008) in Albufera de València Natural Park (Spain). It was part of a substantial effort to restore the former habitats found at the Devesa del Saler, a $14 \mathrm{~km}$ long, $1 \mathrm{~km}$ wide sand bar that separates Albufera de València Lagoon from the Mediterranean Sea. Before the protection of the area, during the 1960s-1970s, an extensive dune system was destroyed as part of an urbanization plan. Citizen mobilizations during the 1980s halted the construction. Since then, many projects have tried to restore the dunes and the typical shallow ponds situated between them.

The LNC has an area of approximately $5900 \mathrm{~m}^{2}$, with a depth of less than $50 \mathrm{~cm}$ in most parts and a maximum depth of $150 \mathrm{~cm}$. Like the rest of the nearby artificial ponds, it is filled by rainfall and groundwater but also influenced by saline spray, resulting in an oligohaline waterbody (bicarbonate alkalinity: $297 \mathrm{mg} / \mathrm{L}$; chloride: $639 \mathrm{mg} / \mathrm{L}$; sulphate: $29 \mathrm{mg} / \mathrm{L}$; calcium: $107 \mathrm{mg} / \mathrm{L}$; magnesium: $58 \mathrm{mg} / \mathrm{L}$; sodium: $365 \mathrm{mg} / \mathrm{L}$ by February 2014). During the period under study, a high density of vegetation (genera Phragmites, Typha, Juncus and Scirpus) emerged on the surface of the pond, whereas scattered meadows of submerged macrophytes covered the bottom. The species Chara hispida dominated other species, mainly by forming monospecific dense beds. Moreover, in some localized areas, $C$. hispida coexisted with the submerged angiosperm Potamogeton pectinatus; in others, with Chara vulgaris and Chara aspera. This latter species was also found forming monospecific clusters in shallower waters, as was Nitella hyalina, which grew in small and localized clusters. The free-floating plant Utricularia australis, which was detected for the first time in the pond in October 2013, coexisted with all other species, as it was distributed across the whole surface of the water.

\section{Monitoring of water conditions and submerged macrophytes}

Temperature data within the pond have been recorded every half hour since July 2013 and since January 2014 with three probes provided with Onset $\mathrm{HOBO}^{\mathrm{R}}$ data loggers (Bourne, MA, USA). One of the probes was set up as an atmospheric sensor in the middle of the pond, whereas the others were tuned as underwater sensors: one of them was submerged $40 \mathrm{~cm}$ from the surface below the atmospheric sensor in an area $120 \mathrm{~cm}$ deep (deeper water), and the other was installed at the eastern edge of the pond in shallower water $(10 \mathrm{~cm}$ from the surface in a $30 \mathrm{~cm}$ deep area) (Fig. 1). Furthermore, from January to July 2014, we quantified some water variables such as $\mathrm{pH}$, conductivity, salinity, and dissolved oxygen monthly, with portable field measuring equipment at three sampling stations (S1, S2 \& S4 in figure 1). Water samples were also taken in these places for sestonic chlorophyll $a$ measurements. These samples were transported in plastic bottles to the laboratory, where they were filtrated through glass microfibre filters (Whatman GF/F, Maidstone, Kent, UK). After chlorophyll extraction with $90 \%$ acetone, sample absorbances were measured with a spectrophotometer to calculate chlorophyll $a$ concentration with the Jeffrey and Humphrey (1975) trichromatic method.

The reproductive phenology of macrophytes was monitored from July 2013 to July 2014. From July 2013 to the end of the year, submerged macrophyte samples were taken sporadically 
from several sites in the pond. From January 2014 onwards, macrophytes were collected from six sampling stations at different depths (Fig. 1). Harvested by hand from the shore of the pond, or with the assistance of a hook, all the macrophytes were collected at a higher frequency in the spring-summer (every 7-10 days) and at a lower frequency in the autumn-winter (once a month). C. hispida was sampled at two stations: S1 (where an inflatable kayak was needed to access the macrophytes) and S4. The rest of the macrophytes were sampled at only one station:

A

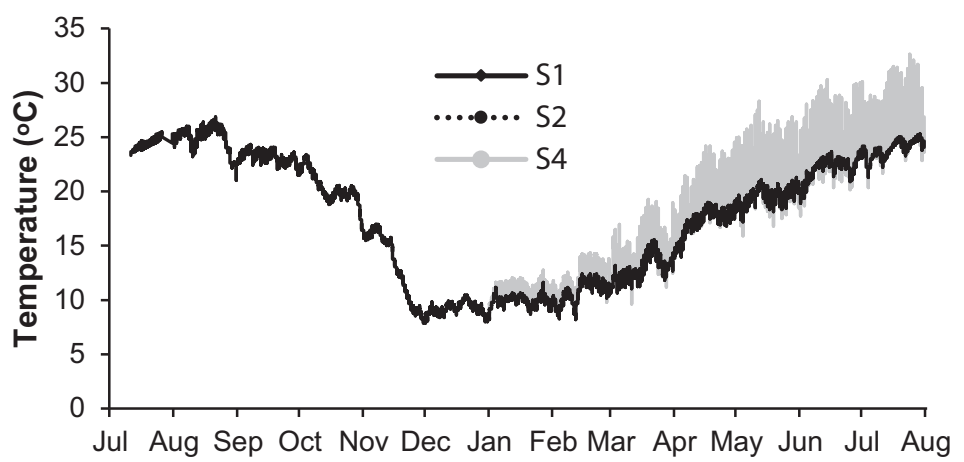

B

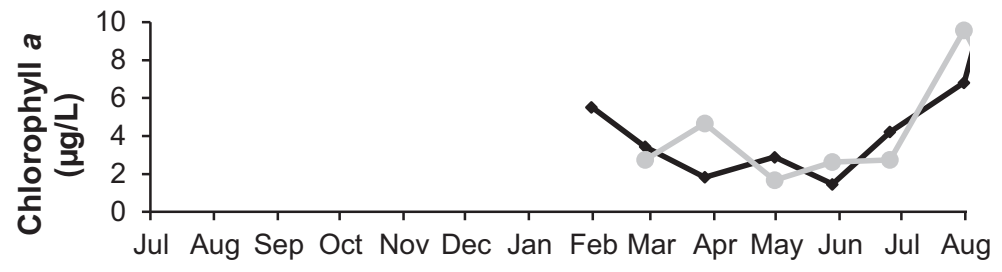

C

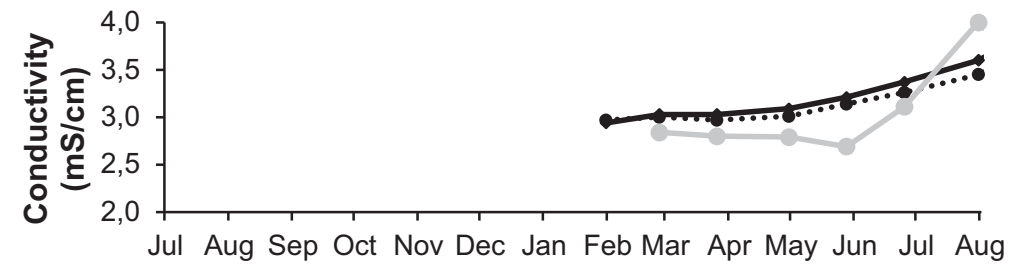

D

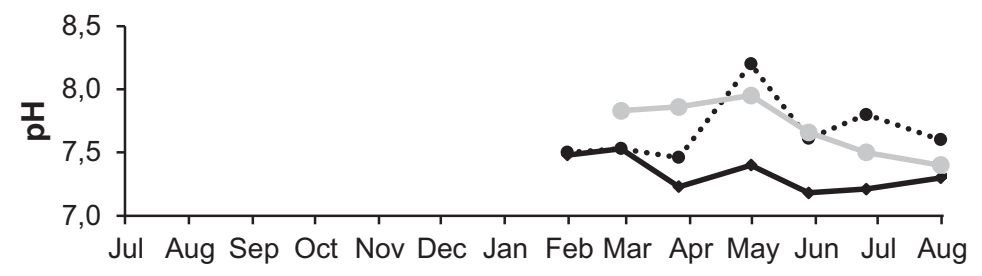

E

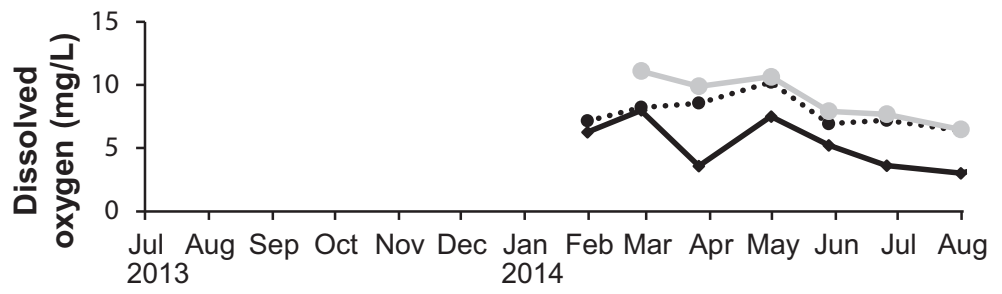

Figure 2. Water conditions from different sampling stations within the Llacuna Nova del Canyar. Underwater temperature (A), sestonic chlorophyll $a$ concentration (B), conductivity (C), $\mathrm{pH}(\mathrm{D})$ and dissolved oxygen data (E) are shown. Condiciones del agua de diferentes estaciones de muestreo de la Llacuna Nova del Canyar. Se muestran los datos de temperatura del agua (A), concentración de clorofila a sestónica $(B)$, conductividad $(C), p H(D)$ y oxígeno disuelto $(E)$. 
C. aspera in $\mathrm{S}^{\prime \prime}$, P. pectinatus in $\mathrm{S} 2, U$. australis in S2" and N. hyalina in S3. C. vulgaris was found spread across different locations such as S1", S2 and S4. All the samples were kept in plastic bags and immediately transported to the laboratory inside an insulated bag provided with coolers. At the laboratory, fresh material was washed to eliminate sediment, epiphytes and other organic matter and kept in tap water in a refrigerator prior to subsequent examination over next few days. Otherwise, samples were fixed in ethanol $(70 \%)$ and further observed. The emergence and maturity of sexual organs was monitored for all the macrophytes with an Olympus ${ }^{\circledR}$ SZ61 binocular loupe (Shinjuku, Tokyo, Japan) with a graduated ocular micrometre. Between 15 and 30 specimens of each species per sampling date and station were observed (except for $C$. vulgaris because only a few specimens of this species were found over the whole period). Flower and seed production was recorded for angiosperms, whereas antheridia (male sexual organs), oogonia (female sexual organs) and oospores (the product of fertilisation of gametes) were observed for charophytes in their unripe/ripe stages.

\section{Data analysis}

Water temperature and phenological features were analysed with a "growing degree-days" approach (Rey-Boissezon \& Auderset Joye, 2012). The Growing Degree-Days (GDD) parameter uses temperature data to estimate the energy accumulated each day over the course of a season (period). It can measure the quantity of heat that an organism requires to develop from one phenophase to another in its life cycle, and, hence it is commonly used to describe and predict phenology (McMaster \& Wilhelm, 1997). We calculated this parameter with the Actual Temperature Method (no cutoff) from the HOBOware $\AA$ Pro Growing Degree Days Assistant (Bourne, MA, USA), which uses the logging interval of the temperature data (30 minutes in this case) to perform a numerical integration. The low threshold of temperature, below which there is no growth of charophytes, is not well-defined (Rey-Boissezon, 2014). For that reason, we established it as the minimum temperature of the annual cycle $\left(7.9^{\circ} \mathrm{C}\right)$. The method described uses the area between the curve and this low threshold to compute the GDD. We used the 1st January as the starting date (biofix). Differences between GDD from shallower and deeper waters were evaluated with a Student t-test (paired samples) using the statistical package IMB ${ }^{\circledR}$ SPSS ${ }^{\circledR} 22.0$ (Armonk, New York, USA). Finally, the analysis of the reproductive life cycle of each species was made according to the GDD of its area of growth, or the most similar one (shallower water for $C$. hispida from S4, C. aspera, C. vulgaris, N. hyalina and $U$. australis; deeper waters for $C$. hispida from S1 and P. pectinatus).

\section{RESULTS}

\section{Water conditions}

The underwater temperature in the middle of the pond (S1) ranged from $8{ }^{\circ} \mathrm{C}$ to $27^{\circ} \mathrm{C}$ during the annual cycle (Fig. 2A). In shallower water (S4), the temperature was more variable than in deeper sites, namely, up to $8{ }^{\circ} \mathrm{C}$ warmer and $2^{\circ} \mathrm{C}$ colder depending on the season and the time of day. Temperature data were different for both areas. Thus, the areas accumulated different amounts of heat $(p<0.05)$, with higher amounts in shallower waters (Fig. 3A).

In general, with rising temperature, the sestonic chlorophyll $a$ concentration increased across the whole pond (Fig. 2B). In S1 and S4, where monospecific beds of $C$. hispida grew, chlorophyll values were approximately $2-5 \mu \mathrm{g} / \mathrm{L}$ during the whole period, reaching a maximum of 7-10 $\mu \mathrm{g} / \mathrm{L}$ by the end of July. The salinity of the pond also rose with increasing temperature, ranging from $1.3 \mathrm{~g} / \mathrm{L}$ to $2.1 \mathrm{~g} / \mathrm{L}$, this being more variable in shallower water (see the dynamic of conductivity in figure $2 \mathrm{C}$ ). The $\mathrm{pH}$ also changed, ranging from 7.2 to 8.2 (Fig. 2D). Dissolved oxygen in water was always higher in shallower water (Fig. 2E), where a dense bed of C. hispida grew and reached the water surface. 
Oxygen decreased when higher temperature and chlorophyll concentration values were found.

\section{Phenology of submerged macrophytes}

\section{Charophytes}

Depending on the depth where shoots were growing, the timing of the emergence of the sexual organs of the species C. hispida varied (Fig. 3A). The $C$. hispida specimens from the middle of the pond and deeper water (S1) developed their first male and female sexual organs simultaneously at the beginning of March, with an accumulated heat of $160 \mathrm{GDD}$. Antheridia ripened first, by the end of the month, and approximately 100 GDD later than the emergence of both types of sexual organs. Approximately one week and 50 GDD
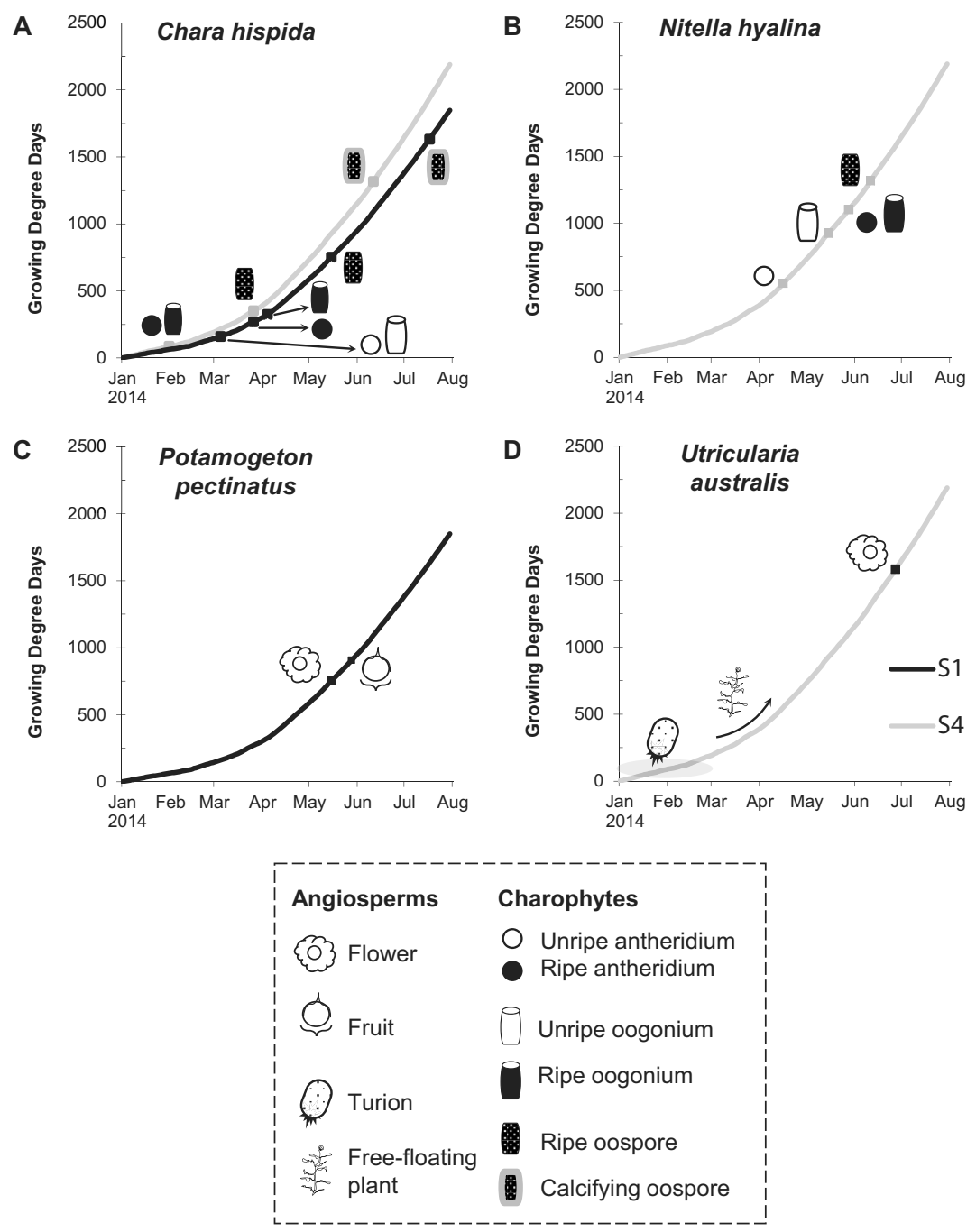

Figure 3. Phenology of Chara hispida (A), Nitella hyalina (B), Potamogeton pectinatus (C) and Utricularia australis (D). The figure shows the moment at which each phenophase appeared for the first time. Schematized phenophases are explained at the bottom of the figure. Fenología de Chara hispida (A), Nitella hyalina (B), Potamogeton pectinatus $(C)$ y Utricularia australis $(D)$. La figura muestra el momento en que cada fenofase apareció por primera vez. La explicación de los esquemas para cada fenofase aparece en la parte inferior de la figura (de arriba a abajo y de izquierda a derecha: Angiospermas / Flor / Fruto / Turión / Planta flotante / Carófitos / Anteridio inmaduro / Anteridio maduro / Oogonio inmaduro / Oogonio maduro / Oóspora madura / Oóspora en proceso de calcificación). 

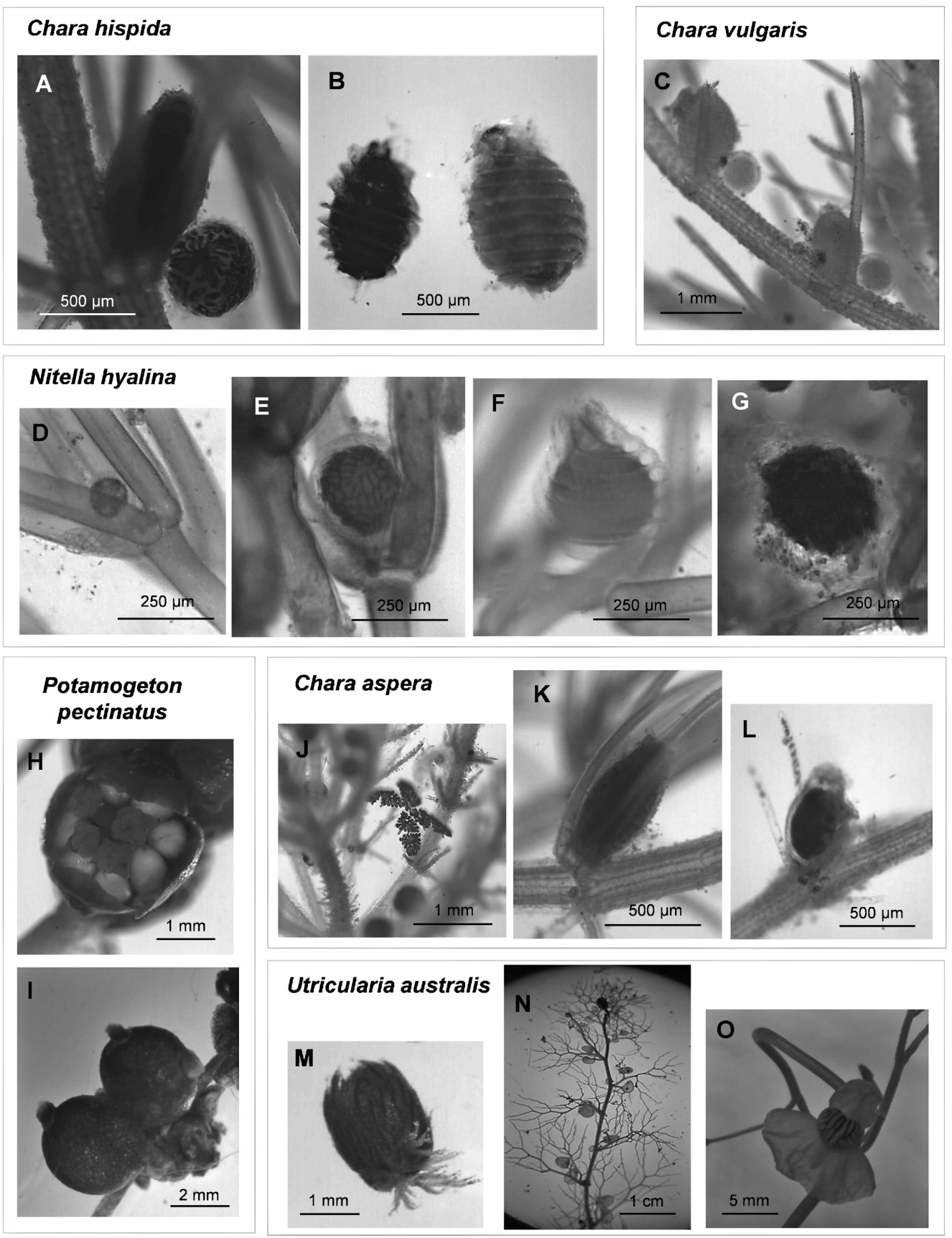

Figure 4. Photographs of different phenophases. Chara hispida: ripe antheridium (the rounded sexual organ) and ripe oogonium (A); ripe oospore (left) and calcifying oospore (B). Chara vulgaris: ripe antheridium (the rounded sexual organ) and ripe oogonium (C). Nitella hyalina: unripe antheridium (the rounded sexual organ) and unripe oogonium (D); ripe antheridium (E); ripe oogonium $(\mathrm{F})$; ripe oospore $(\mathrm{G})$. Potamogeton pectinatus: flower $(\mathrm{H})$; fruits (I). Chara aspera: open antheridium (J); ripe oogonium (K); ripe oospore (L). Utricularia australis: turion (M); free-floating plant (N); flower (O). Fotografías de las distintas fenofases observadas. Chara hispida: anteridio maduro (el órgano sexual redondo) y oogonio maduro (A); oóspora madura (izquierda) y oóspora en proceso de calcificación $(B)$. Chara vulgaris: anteridio maduro (el órgano sexual redondo) y oogonio maduro $(C)$ ). Nitella hyalina: anteridio inmaduro (el órgano sexual redondo) y oogonio inmaduro $(D)$; anteridio maduro $(E)$; oogonio maduro $(F)$; oóspora madura $(G)$. Potamogeton pectinatus: flor $(H)$; frutos $(I)$. Chara aspera: anteridio abierto $(J)$; oogonio maduro $(K)$; oóspora madura $(L)$. Utricularia australis: turión $(M)$; planta flotante $(N)$; flor $(O)$. 
afterwards, the first ripe oogonia were observed (Fig. 4A). Finally, the first oospores appeared in mid-May at 750 GDD and started to calcify by mid-July (1630 GDD; Fig. 4B). From the beginning of April to late June, all the sampled shoots were fertile and showed sexual organs. By contrast, $C$. hispida from the eastern edge of the pond and shallower waters (S4) already had ripe sexual organs at the first sampling date, equivalent to 70 GDD. The shoots showed their first oospores by the end of March (350 GDD) and started to calcify in early June (1300 GDD). The period of maximum fertility, with $100 \%$ of the shoots fertile, ranged from early March (215 GDD) to late June (1550 GDD).

The phenology of $N$. hyalina was similar to C. hispida, although $N$. hyalina became fertile later in the year and required more accumulated heat to do so (Fig. 3B). Antheridia emerged in mid April at 550 GDD, whereas the first oogonia appeared a month later (Fig. 4D), at 930 GDD, when $50 \%$ of the specimens had at least one sexual organ. The first ripe antheridia and oogonia were observed by the end of May (1100 GDD; Fig. 4E-F). In early June, at 1320 GDD and with $60 \%$ of the shoots fertile, the first oospores appeared (Fig. 4G). By the end of the period under study, up to $70 \%$ of the sample specimens had sexual organs.

C. vulgaris was found almost nowhere in the pond. Of the 10 shoots found during the whole study period, only 3 of them from shallower waters were fertile. They showed ripe antheridia and oogonia in early and mid-June (Fig. 4C), at approximately 420 GDD. C. aspera specimens were localized by early March, at 200 GDD, when some of them already had ripe antheridia, ripe oogonia and even ripe oospores (Fig. 4J-L).

\section{Angiosperms}

The two studied angiosperms flowered in late spring and mid-summer (Fig. 3C-D). Potamotegon pectinatus showed its first flowers on 15 May with an accumulated heat of 750 GDD, whereas the first fruits appeared on 28 May at 900 GDD (Fig. 4H-I). From that moment until 17 July (1700 GDD), approximately $20 \%$ of the plants under study were fertile, this being the period of maximum fertility. By the end of the period under study, no specimen of $P$. pectinatus was fertile. Meanwhile, Utricularia australis was in its vegetative hibernating form (turion) until the $26^{\text {th }}$ February (180 GDD), when the first free floating plants emerged (Fig. 4M-N). The first flowers appeared in summer, by 27 June (1600 GDD; Fig. 4O). Neither fruits nor seeds were detected during the period under study.

\section{DISCUSSION}

Studies on the reproductive phenology of submerged macrophytes are scarce, particularly in the case of charophytes (Rey-Boissezon, 2014). In fact, this study represents the first on the detailed phenology of Mediterranean charophytes from wetlands that includes information about the accumulated heat required to produce sexual structures. It is a first glance at the life cycle of the submerged macrophytes from LNC, and it provides information about basic environmental conditions that affect the phenology of aquatic plants, such as temperature, and which, in turn, are also influenced by climate change. In a semiarid region such as the Mediterranean littoral areas of Spain, where lakes and other large waterbodies are scarce, this small wetland pond is quite rich in submerged macrophytes (two angiosperm and four charophyte species), constituting a suitable scenario to monitor and compare the phenology of all these species. Moreover, some of the species being studied are particularly important for the conservation of biodiversity. N. hyalina is a charophyte species catalogued as "vulnerable" in the Spanish territory (Cirujano et al., 2008) and it has recently become extinct in several European countries (Auderset \& Schwarzer, 2012). The free floating plant Utricularia australis is catalogued as "endangered" in the regional legislation (Aguilella et al., 2009). Its recent appearance in LNC represents a perfect opportunity to monitor its life cycle in the wetlands of the region, where information is also scarce. Thus, with this study, we attempt to understand the responses of macrophytes to some basic environ- 
mental factors, as well as to highlight the value of wetlands -shallow ecosystems, hence more affected by temperature changes- to better understand the processes involved in the phenological changes related to climate change.

In general, charophytes from LNC seem to be perennial because they grew during the whole year in both shallower and deeper waters. $C$. hispida from $\mathrm{S} 1$ and $N$. hyalina were fertile during spring (from March-April) and summer, according with the findings of Vromans et al. (2013) for Chara sp. in estuaries, where sexual reproduction happened in the same season and for a period of 3-7 months. However, for the species living in shallower water (such as $C$. hispida from $\mathrm{S} 4$ or $C$. aspera), there was no clear interruption of the production of sexual organs during the period studied. In fact, Bonis et al. (1993) found that C. aspera, among other charophytes, produced sexual organs even during autumn in experimental outdoors communities, although maturation was not detected. Similarly, the period of maximum fertility for $C$. hispida (100\% of fertile plants) was longer in shallower water compared to deeper water. These results agree with the findings of Asaeda et al. (2007) concerning $N$. hyalina and $C$. fibrosa, whose meadows from shallower water have shorter life cycles and higher rates of sexual organ production than meadows from deeper water. They assumed that the total shoot length of meadows from shallow water -approximately $30 \mathrm{~cm}$, and similar to the length of $C$. hispida in S4 (LNC)could have grown in 60 days, and so the species would have proliferated in just a few months.

Observations of $C$. hispida and $N$. hyalina specimens showed that antheridia generally required less accumulated heat in order for them to be produced compared to oogonia, so that male organs appeared before throughout the growing season, according to the phenomenon of protandry largely described for charophytes (Guerlesquin, 1987). The sexual organs that form a couple in these monoecious species (both sexes on the same specimen) have an interrelated growing dynamic, but when the antheridium stops growing and ripens, the oogonium keeps developing (Kwiatkowska et al., 1997). Thus, maturation of antheridia from the same whorl of a specimen comes before the maturation of oogonia from that same whorl.

The charophyte that required the greatest GDD to become fertile was $N$. hyalina. This species needed 1300 GDD to ripen oospores, approximately 500 and 1000 more than $C$. hispi$d a$ from $\mathrm{S} 1$ and $\mathrm{S} 4$, respectively. These two populations of $C$. hispida behaved differently, as specimens became fertile and sexual organs ripened before -in both time and heat requirements- in warmer (shallower) water. Swiss researchers have also described large differences between the life cycles of two Swiss populations of the same species. In this case, however, the charophyte under study was Nitella gracilis and it required nearly half the number of GDD to develop from one phenophase to another in colder habitats, although they became fertile and their sexual organs ripened slightly later in the year (Rodrigo et al., 2013). These differing results for the same species suggest that GDD is not the only factor driving the reproductive phenology of charophytes, although it may be the main factor as stated by Rey-Boissezon (2014) in the first description of a degree-day-based life cycle of a charophyte. This author characterized the dioecious species (with separated sexes: female and male shoots) Nitellopsis obtusa. However, there is still no evidence whether monoecism or dioecism is a factor driving the heat requirements of the species.

Although we have found that angiosperms required more accumulated heat than charophytes to become fertile, both plants and macroalgae produced and ripened their sexual organs before the temperature peak of summer, so they can be considered early-blooming species. According to Sherry et al. (2007), increasing temperatures may advance the reproductive phenology of this type of plant. In fact, higher temperatures and an early start of the growing season affect biomass and distribution of submerged macrophytes (Rooney \& Kalff, 2000), so that these communities are suitable candidates to help monitor the effects of warming from climate change. Experiments with both angiosperms and charophytes (Mckee et al., 2002; Rojo et al., 2015) note that small 
increases of $2-4{ }^{\circ} \mathrm{C}$, such as the ones expected for the Mediterranean region by the end of this century, affect their flowering and growth. The present study is the beginning of a long-term data series of investigations on the phenology of submerged aquatic plants with the main aim of analysing and predicting their responses to the foreseeable changes in temperature associated with climate change. We expect that further research will allow us to discuss whether charophytes or angiosperms are more appropriate as trackers of increasing temperature.

However, temperature is not the only factor determining phenology. Multiple environmental cues such as precipitation, irradiance or photoperiod are sometimes required to trigger the production of sexual organs in plants (Pau et al., 2011). Experiments on charophytes showed that the photoperiod considerably affects the growth and final size of antheridia (Kwiatkowska et al., 1997), whereas field studies note the importance of depth and light intensity on the size of oospores (Boszke \& Bociag, 2008). In the case of $N$. hyalina from LNC, although growing in shallow water, the specimens grew at the base of emergent plants (Typha sp.) and were widely covered by the free-floating $U$. australis most of the time. The lack of sufficient light availability might have been the reason why this species developed its sexual organs so late. Hence, we recently started to continuously monitor underwater light availability in the LNC to address the role of these other variables in submerged macrophyte fertility in the future. Moreover, the local community composition can also affect the reproductive phenology of the species (Pau et al., 2011). For example, the overgrowing of free floating plants can produce shading effects on submerged macrophytes and alter the whole structural complexity of the system (Meerhoff et al., 2007). In fact, in some areas of LNC, $U$. australis blooming was such that almost no light $\left(<25 \mu \mathrm{mol} \mathrm{m}{ }^{-2} \mathrm{~s}^{-1}\right)$ penetrated at $30 \mathrm{~cm}$ depth by the end of July (Calero et al., unpublished data).

As mentioned before, the data presented here are just initial data, but they lay the foundation for our forthcoming research. We expect that this first long-term data series concerning the phenology of submerged macrophytes from Mediterranean wetlands will contain both cooling and warming periods (Sparks \& Tryjanowski, 2005) that will allow us to describe the macrophytes' phenology and also the effects of the current changing environment over phenological events, bringing new insights into the response of these species in the face of global change.

\section{ACKNOWLEDGEMENTS}

Sara Calero is the holder of a grant from the Spanish government (Ministry of Education, Culture and Sport: FPU13/02254). We are very grateful to Joan Miquel Benavent (Oficina Devesa-Albufera, Ajuntament de València) for his collaboration in the initial phase of the study and to Lila Reinhard for her field and laboratory assistance. We also acknowledge the permissions to study the pond facilitated by Oficina Tècnica Devesa-Albufera (Ajuntament de València), and Servei de Parcs Naturals and Servei de Vida Silvestre from Direcció General del Medi Natural of Conselleria d'Infraestructures, Territori $i$ Medi Ambient (Generalitat Valenciana). The English-language text was edited by Daniel Sheerin (Online English S.C.) and finally by American Journal Experts. Two anonymous reviewers contributed suggestions.

\section{REFERENCES}

AGUIAR, F. C., P. SEGURADO, G. URBANIČ, J. CAMBRA, C. CHAUVIN, S. CIADAMIDARO, G. DÖRFLINGER, J. FERREIRA, M. GERM, P. MANOLAKI, M. R. MINCIARDI, A. MUNNÉ, E. PAPASTERGIADOU \& M. T. FERREIRA. 2014. Comparability of river quality assessment using macrophytes: a multi-step procedure to overcome biogeographical differences. Science of the Total Environment, 476: 757-767.

AGUILELLA, A., S. FOS \& E. LAGUNA. 2009. Catálogo Valenciano de Especies de Flora Amenazadas. Conselleria de Medi Ambient, Aigua, Urbanisme i Habitatge, Generalitat Valenciana. Valencia. Spain. 
ALAHUHTA, J., J. HEINO \& M. LUOTO. 2011. Climate change and the future distributions of aquatic macrophytes across boreal catchments. Journal of Biogeography, 38(2): 383-393.

ASAEDA, T., L. RAJAPAKSE \& B. SANDERSON. 2007. Morphological and reproductive acclimations to growth of two charophyte species in shallow and deep water. Aquatic Botany, 86(4): 393-401.

AUDERSET JOYE, D. \& A. SCHWARZER. 2012. Liste Rouge Characées. Espèces menacées en Suisse, état 2010. Office fédéral de l'environnement, Berne; Laboratoire d'écologie et de biologie aquatique de l'Université de Genève, Genève, Switzerland.

AUDERSET JOYE, D. \& A. REY-BOISSEZON. 2015. Will charophyte species increase or decrease their distribution in a changing climate? Aquatic Botany, 120: 73-83.

BONIS, A., P. GRILLAS, C. WIJCK \& J. LEPART. 1993. The effect of salinity on the reproduction of coastal submerged macrophytes in experimental communities. Journal of Vegetation Science, 4(4): 461-468.

BOSZKE, P. \& K. BOCIĄG. 2008. Morphological variation of oospores in the population of Chara rudis A. Braun in a mesotrophic lake. Polish Journal of Ecology, 56(1): 139-147.

CARPENTER, S. R. \& D. M. LODGE. 1986. Effects of submersed macrophytes on ecosystem processes. Aquatic Botany, 26: 341-370.

CHUINE, I., G. CAMBON \& P. COMTOIS. 2000. Scaling phenology from the local to the regional level: advances from species-specific phenological models. Global Change Biology, 6(8): 943-952.

CIRUJANO, S., J. CAMBRA, P. SÁNCHEZ CASTILLO, A. MECO \& N. FLOR ARNAU. 2008. Flora ibérica. Algas continentales. Carófitos (Characeae). Real Jardín Botánico, CSIC-Universidad de Barcelona. Spain.

DONNELLY, D., A. CAFFARRA \& B. F. O'NEILL. 2011. A review of climate-driven mismatches between interdependent phenophases in terrestrial and aquatic ecosystems. International Journal of Biometeorology, 55: 805-817.

ERWIN, K. L. 2009. Wetlands and global climate change: the role of wetland restoration in a changing world. Wetlands Ecology and Management, 17(1): 71-84.

GUERLESQUIN, M. 1987. Recherches récentes sur les Charophycées: morphogenèse et reproduction sexuée. Bulletin de la Société Botanique de France. Actualités Botaniques, 134(1): 17-30.

JEFFREY, S. W. \& G. P. HUMPHREY. 1975. New spectrophotometric equations for determining chlorophylls a, b, c1 and c2 in higher plants, algae and natural phytoplankton. Biochemie und Physiologie der Pflanzen, 19: 191-194.

KWIATKOWSKA, M., A. PALA \& J. MASZEWSKI. 1997. Size-variation in the antheridia and oogonia of Chara vulgaris under different experimental conditions. Acta Societatis Botanicorum Poloniae, 66(1): 29-32.

LACOUL, P. \& B. FREEDMAN. 2006. Environmental influences on aquatic plants in freshwater ecosystems. Environmental Reviews, 14(2): 89-136.

MCKEE, D., K. HATTON, J. W. EATON, D. ATKINSON, A. ATHERTON, I. HARVEY \& B. MOSS. 2002. Effects of simulated climate warming on macrophytes in freshwater microcosm communities. Aquatic Botany, 74(1): 71-83.

MCMASTER, G. S. \& W. W. WILHELM. 1997. Growing degree-days: one equation, two interpretations. Agricultural and Forest Meteorology, 87: 291-300.

MEERHOFF, M., J. M. CLEMENTE, D. MELLO, F. TEIXEIRA, C. IGLESIAS, A. R. PEDERSEN \& E. JEPPESEN. 2007. Can warm climate-related structure of littoral predator assemblies weaken the clear water state in shallow lakes? Global Change Biology, 13(9): 1888-1897.

NETTEN, J. J., J. VAN ZUIDAM, S. KOSTEN \& E. T. PEETERS. 2011. Differential response to climatic variation of free-floating and submerged macrophytes in ditches. Freshwater Biology, 56(9): 1761-1768.

PARMESAN, C. 2006. Ecological and evolutionary responses to recent climate change. Annual Review of Ecology and Systematics, 37: 637-669.

PAU, S., E. M. WOLKOVICH, B. I. COOK, T. J. DAVIES, N. J. B. KRAFT, K. BOLMGREN, J. L. BETANCOURT \& E. E. CLELAND. 2011. Predicting phenology by integrating ecology, evolution and climate science. Global Change Biology, 17(12): 3633-3643.

PEETERS, E. T. H. M., J. P. VAN ZUIDAM, B. G. VAN ZUIDAM, E. H. VAN NES, S. KOSTEN, P. G. M. HEUTS, R. M. M. ROIJACKERS, J. J. C. NETTEN \& M. SCHEFFER. 2013. Changing weather conditions and floating plants in temperate drainage ditches. Journal of Applied Ecology, 50: 585-593. 
REY-BOISSEZON,A. \& D. AUDERSET JOYE. 2012. A temporary gravel pit as a biodiversity hotspot for aquatic plants in the Alps. Archive des Sciences, 65: 177-190.

REY-BOISSEZON, A. 2014. Distribution et dynamique des communautés de Characées: Impact des facteurs environnementaux régionaux et locaux. Ph.D. Thesis. Université de Genève, Switzerland.

RICHARDSON, A. D., T. F. KEENAN, M. MIGLIAVACCA, Y. RYU, O. SONNENTAG \& M. TOOMEY. 2013. Climate change, phenology, and phenological control of vegetation feedbacks to the climate system. Agricultural and Forest Meteorology, 169: 156-173.

RODRIGO, M. A., D. AUDERSET JOYE, W. COLOM, \& A. REY-BOISSEZON. 2013. The importance of research on the phenology of submerged macrophytes at a global scale. ECOGENES Conference: Adapting to Global Change in the Mediterranean hotspot. September 18-20, 2013. http: //ebdecogenes.ebd.csic.es/images/posters/Rodrigo_Auderset_et_al_Seville\%202013.pdf

ROJO, C., C. MARTÍNEZ-RUIZ, M. CARRAMIÑANA \& M. A. RODRIGO. 2015. Foreseeable global warming will differentially affect Chara vulgaris populations from different altitudes. Aquatic Botany, DOI: 10.1016/j.aquabot.2014.12.002.

ROONEY, N. \& J. KALFF. 2000. Inter-annual variation in submerged macrophyte community biomass and distribution: the influence of temperature and lake morphometry. Aquatic Botany, 68(4): 321-335.

SHERRY, R. A., X. ZHOU, S. GU, J. A. ARNONE, D. S. SCHIMEL, P. S. VERBURG, L. L. WALLACE \& Y. LUO. 2007. Divergence of reproductive phenology under climate warming. Proceedings of the National Academy of Sciences, 104(1): 198-202.

SPARKS, T. H. \& P. TRYJANOWSKI. 2005. The detection of climate impacts: some methodological considerations. International Journal of Climatology, 25(2): 271-277.

VITOUSEK, P. M. 1994. Beyond global warming: ecology and global change. Ecology, 75(7): 18611876.

VROMANS, D. C., J. B. ADAMS \& T. RIDDIN. 2013. The phenology of Ruppia cirrhosa (Petagna) Grande and Chara sp. in a small temporarily open/closed estuary, South Africa. Aquatic Botany, 110: $1-5$. 